\title{
Water, sodium, potassium, and chloride content of skeletal muscle in fit and ill subjects
}

\author{
C. T. G. FLEAR, IRENÉ FLORENCE, AND J. A. WILliAMS \\ From the University Department of Clinical Biochemistry, Royal Victoria Infirmary, Newcastle upon Tyne, and \\ the Nutritional and Intestinal Unit, the General Hospital, Birmingham
}

SYNOPSIS Biopsies of deltoid, gastrocnemius, or rectus abdominis taken under general anaesthesia from each of 15 subjects have been analysed for fat, water, sodium, potassium, and chloride. Some 110 samples were analysed for each muscle, and all the estimations were made on each sample. Standards have been constructed for the normal composition of these three muscles, and their reliability is discussed.

Data from subjects with peptic ulcer, hyponatraemia, and sustained weight loss must be excluded from standards. It seems likely that standards could be improved by taking age and sex into account.

Considerable variation exists in the water, sodium, potassium, and chloride contents of small (15 to 30 mg) samples of human skeletal muscle (Flear and Florence, 1963; Flear, Carpenter, and Florence, 1965). Happily, water content closely correlates with the amount of sodium plus potassium in samples: potassium and sodium contents are negatively correlated, and sodium and chloride contents show a strong positive correlation (Flear and Florence, 1963; Flear et al, 1965). When this orderliness is taken into account, individual samples afford a good index of the composition throughout the muscle sampled, and, if normal standards were available, it should be possible to appraise the composition of muscle in ill patients.

For a definitive appraisal, it is necessary to compare the composition of such biopsies with standards compiled for the same muscle, first because of differences in intercepts or slopes of the regression lines, potassium on sodium (Flear et al, 1965) or water on sodium plus potassium (Flear, Carpenter, and Florence, unpublished), and secondly, as standards compiled from samples of several different muscles would have a wider scatter of values about the various regressions (Flear et al, 1965). This paper presents standards for three muscles: deltoid, gastrocnemius, and rectus abdominis. The reliability of these standards is discussed, and the composition of samples of rectus abdominis from ill subjects are compared with the standards constructed for that muscle.

Received for publication 23 January 1968.

\section{MATERIALS AND METHODS}

SUBJECTS Initially deltoid, gastrocnemius, or rectus abdominis muscle was sampled in 45 subjects (Table I). Each muscle was sampled in 15 subjects and standards were constructed from these data. Deltoid was sampled in two females (ages 41 and $67 \mathrm{yr}$ ) and 13 males (average age 48; range 17-66 yr), gastrocnemius in seven females (average age $50 \mathrm{yr}$; range 34-69 yr) and eight males (average age $45 \mathrm{yr}$; range $33-68 \mathrm{yr}$ ), rectus abdominis in six females (average age $58 \mathrm{yr}$; range 46-63 yr), and nine males (average age $55 \mathrm{yr}$; range $42-71 \mathrm{yr}$ ). All those subjects whose deltoid or gastrocnemius muscles were sampled were fit. Rectus abdominis was sampled in nine fit subjects; in four persons who before operation were considered to be reasonably fit, although subsequent events led us to revise this evaluation; and in two other subjects who could not be considered fit, but were without overt abnormality of water and electrolyte metabolism.

TABLE I

SAMPLES FROM FIT AND CONTROL SUBJECTS

\begin{tabular}{llll} 
Condition or Operation & Muscle & \\
\cline { 2 - 3 } & Deltoid & Gastrocnemius & $\begin{array}{l}\text { Rectus } \\
\text { Abdominis }\end{array}$ \\
\hline
\end{tabular}

\section{Fit subjects}

Varicose veins

Hernia or hydrocele

Minor surgery

(lipoma, cysts, etc )

Appendicectomy ('cold')

Papilloma of bladder

Gallstones (uncomplicated)

Controls

Peptic ulcer

Carcinomatosis

Obstruction-bile duct 
At the time, it was considered acceptable to include these six subjects among a control group. For reasons which are discussed, we now believe that this decision was incorrect. The six subjects in question are therefore referred to as 'control' subjects in Table I.

Subsequently samples of rectus abdominis were taken from a further five subjects (Table II) chosen because they had lost weight. Four of the five were definitely unwell. Disturbances of water and electrolyte metabolism seemed likely in only one of these persons. He suffered from ulcerative colitis and was admitted for a planned hemicolectomy during a phase of remission, after taking supplements of potassium daily for many weeks.

STANDARDS FOR MUSCLE COMPOSITION For both deltoid and gastrocnemius these are based upon data from the 15 fit subjects (Table I). For rectus abdominis, they are based upon data from the nine fit subjects in Table I only.

SAMPLING PROCEDURE AND ANALYSIS Biopsies were taken at operation: deltoid and gastrocnemius and sometimes rectus abdominis muscles were sampled through an elective incision. Most samples of rectus abdominis were taken from an area not exposed by the abdominal incision entailed by the operation, which was therefore extended for this purpose. Samples were usually taken at the beginning of the operation, sometimes towards its end; all were placed immediately into sterile acid-washed bottles ( $\bumpeq 25 \mathrm{ml}$ capacity) with screw tops, which were then placed in a vacuum flask containing solid carbon dioxide. Biopsies taken at the end of an operation were all from an area of muscle that had not been exposed or handled during the operation. Samples were processed for analysis, as previously described (Flear and Florence, 1961) after an interval of not more than three hours from the time they were taken. Water, fat, sodium, and potassium were determined as previously described (Flear and Florence, 1961) ${ }^{\mathbf{1}}$; chloride was estimated in the nitric acid $(0 \cdot 1 \mathrm{~N})$ extract by amperometric titration (Cotlove, Trantham, and Bowman, 1958) using an American Instrument Company Cotlove chloridimeter.

${ }^{1}$ In this method, slices of muscle are placed on to weighed aluminium pans on which they remain throughout. Disposable pans made from aluminium sheeting (thickness, 0.001 in. to 0.005 in.) are available from the Corrugated Packing and Sheet Metal Co. Ltd, Hamsterley, Newcastle upon Tyne.
POSSIBLE ERRORS IN ESTIMATING TISSUE WATER CONTENT음 Preliminary experiments established (1) that water was not lost from biopsies placed in stoppered bottles inside a $\overline{\overline{\overrightarrow{ }}}$ vacuum flask containing solid carbon dioxide for ato least 48 hours; (2) that a biopsy loses a significant amount $\frac{\bar{C}}{\partial}$ of water in the operating theatre if there is delay of more $\frac{\bar{c}}{\bar{c}}$ than about 30 min between taking it and placing it in its bottle. Slices cut from the centre of biopsies left for this 2 time were found to contain less water. Error introduced by neglecting evaporation during the time taken to cut and weigh slices ( $\bumpeq 2 \mathrm{~min}$ ) was shown to be negligible. $A^{\circ}$. $25 \mathrm{mg}$ slice from a biopsy containing $75 \%$ water would be $\vec{\overrightarrow{ }}$ found from analysis to contain $74.95 \%$ water, an underestimate of less than $0 \cdot 1 \%$.

\section{RESULTS}

FIT AND CONTROL SUBJECTS Analytical findings are presented in Figs. 1 to 3 and 5, summarizing our음 statistics in Fig. 4, and in Tables III to VII. As previ--

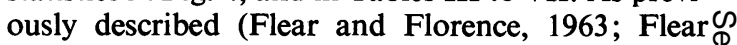
et al, 1965), negative correlations obtain between sample contents of sodium and potassium when $\frac{\mathbb{D}}{3}$ quoted as amounts per litre tissue water, per kilogram wet weight or fat-free wet weight and per kilogram fat-free dry weight of tissue but not when dry weight of tissue is the reference base. Negative. correlations also exist between sample contents of chloride and potassium but not when amounts are quoted per kilogram dry weight of tissue. Positive correlations obtain between sample contents of sodium and chloride and between the amounts of $\stackrel{\square}{\square}$ water and the sum of sodium plus potassium $(\mathrm{Na}+\overline{\bar{O}}$ $\mathrm{K})$, whichever reference base is used.

Individual values for potassium show a somewhat greater scatter about the regression lines for $\mathrm{K}$ on $\mathrm{Cl}$ than about the regression lines $\mathrm{K}$ on $\mathrm{Na}$. Coefficients of variation of single estimates of potassium, when account is also taken of chloride content of the sample, are $6.7 \%, 5.4 \%$, and $4.9 \%$ for deltoid, gastrocnemius, and rectus abdominis in the nine fit subjects respectively, when amounts are quoted per

TABLE II

RESULTS IN SAMPLES OF RECTUS ABDOMINIS MUSCLE FROM ILL SUBJECTS

Condition Sex Age Recent Weight Loss Condition

Serum Levels (m-equiv/l. or $\mathrm{mg} / 100 \mathrm{ml}$ ).

$\overrightarrow{\mathrm{Na}} \mathrm{K} \quad \mathrm{Cl}$ Urea

\begin{tabular}{lrrl}
\hline Bile vomiting & F & 47 & $\begin{array}{l}\text { 6 lb in preceding year } \\
\text { 12 lb }\end{array}$ \\
Postgastrectomy & F & 49 & $\begin{array}{l}\text { Weight considerably less than } \\
\text { standard for height }\end{array}$ \\
Duodenal ulcer & M & 56 & $\begin{array}{l}\text { Weight less than standard for } \\
\text { height: very poor appetite } \\
\text { Weight less than standard for } \\
\text { height }^{2}\end{array}$ \\
Ulcerative colitis & M & 51 &
\end{tabular}

III

Very poor

Very poor ${ }^{1}$

In remission;

admitted for surgery

$\begin{array}{rrrr}140 & 4 \cdot 1 & 105 & 53 \\ 137 & 4 \cdot 5 & 97 & 21 \\ 140 & 4 \cdot 6 & 102 & 29 \\ 132 & 4 \cdot 8 & 98 & 36 \\ 141 & 4 \cdot 6 & 102 & 35\end{array}$

'Vomiting was not a feature.

${ }^{2}$ This patient gained a considerable amount of weight in the months after hemicolectomy. 
FIG. 1. Relation between sodium and potassium contents of samples. Data for deltoid and gastrocnemius are from 15 fit subjects, and for rectus from nine fit subjects and six others initially considered as 'controls' (see Table I). The calculated regression lines for potassium on sodium and the $90 \%$ confidence limits of the individual estimations (Tables III-VII) are shown.
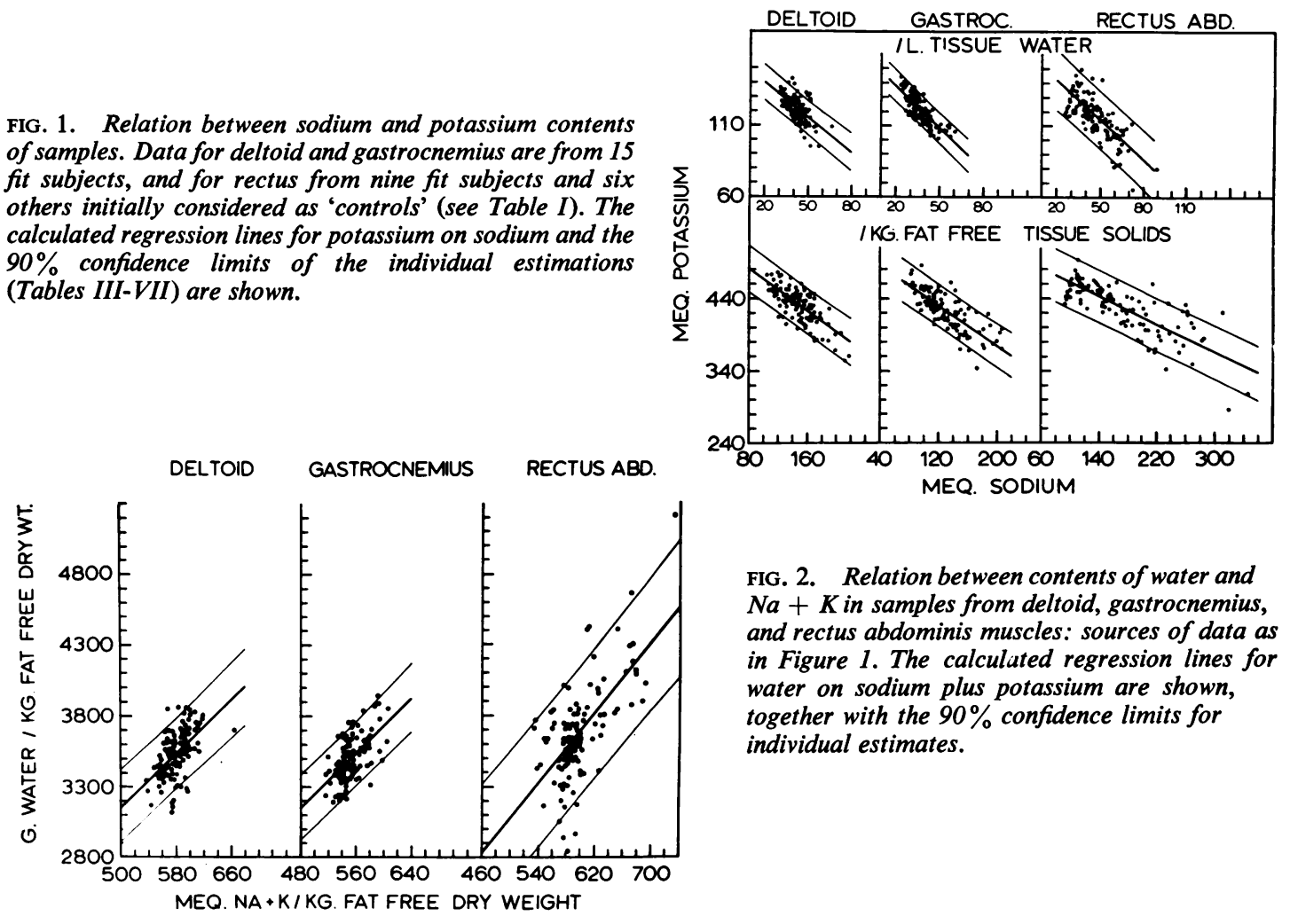

FIG. 2. Relation between contents of water and $\mathrm{Na}+\mathrm{K}$ in samples from deltoid, gastrocnemius, and rectus abdominis muscles: sources of data as in Figure 1. The calculated regression lines for water on sodium plus potassium are shown, together with the $90 \%$ confidence limits for individual estimates.
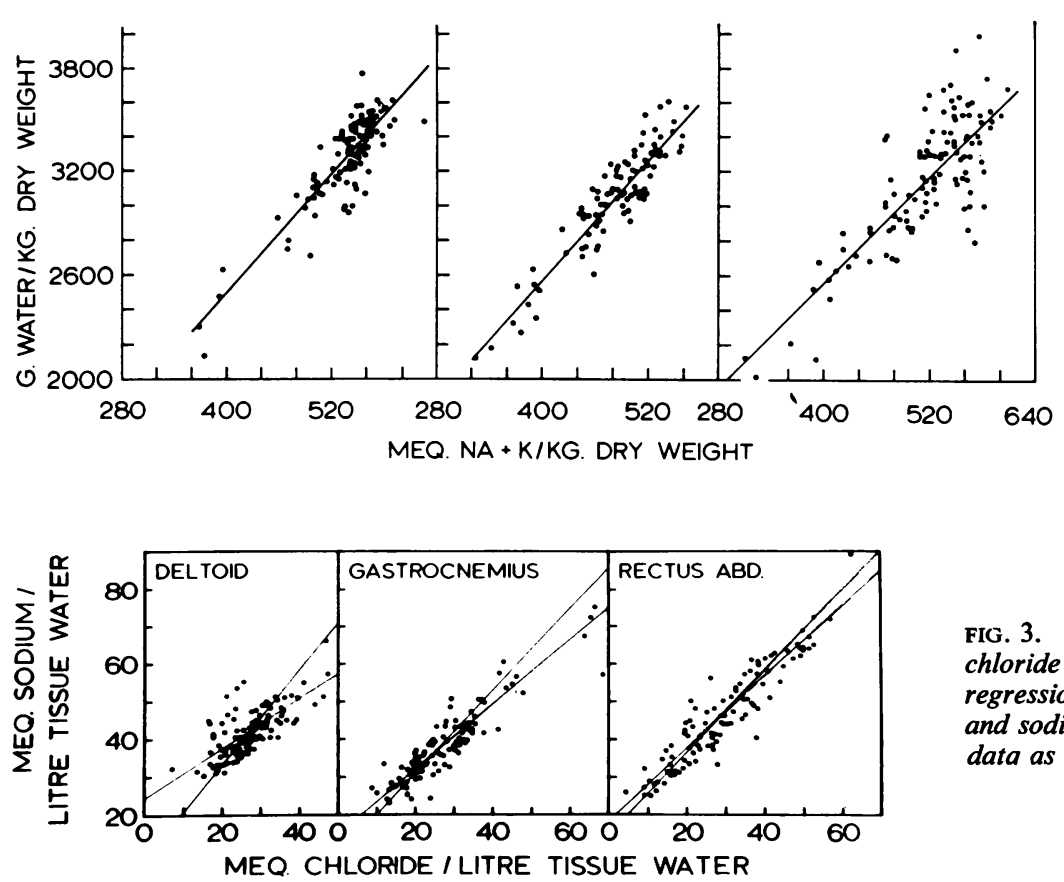

FIG. 3. Sample contents of sodium and chloride together with the fitted regression lines chloride on sodium and sodium on chloride: sources of data as in Figure 1. 
TABLE III

SUMMARY OF STATISTICS FOR DATA FROM DELTOID, GASTROCNEMIUS, AND RECTUS ABDOMINIS MUSCLE IN FIT AND CONTROL SUBJECTS

\begin{tabular}{|c|c|c|c|c|c|c|c|c|c|}
\hline & \multicolumn{3}{|c|}{ Potassium (y) (m-equiv/kg) } & \multicolumn{3}{|c|}{ Sodium $(x)$} & \multicolumn{3}{|c|}{$\begin{array}{l}\text { Chloride }(y) \text { : Sodium }(x) \\
(m-e q u i v / k g \text { tissue water })\end{array}$} \\
\hline & \multicolumn{3}{|c|}{ Fat-free Dry Weight of Tissue } & \multicolumn{3}{|c|}{ Tissue Water } & \multirow[b]{2}{*}{$d^{1}$} & \multirow[b]{2}{*}{$g^{2}$} & \multirow[b]{2}{*}{$r^{3}$} \\
\hline & $d^{1}$ & $g^{2}$ & $r^{3}$ & $d^{1}$ & $g^{2}$ & $r^{3}$ & & & \\
\hline $\begin{array}{l}\mathbf{r} \\
\text { by } \\
E^{4}\end{array}$ & $\begin{array}{l}-0.690 \\
-0.729 \\
-539.6\end{array}$ & $\begin{array}{r}-0.774 \\
-0.690 \\
513.4\end{array}$ & $\begin{array}{r}-0.795 \\
-0.483 \\
510.4\end{array}$ & $\begin{array}{r}-0.603 \\
-0.821 \\
156.3\end{array}$ & $\begin{array}{r}-0.787 \\
-0.983 \\
157.5\end{array}$ & $\begin{array}{r}-0.702 \\
-0.926 \\
160 \cdot 1\end{array}$ & $\begin{array}{r}+0.713 \\
+0.801 \\
-\quad 6.5\end{array}$ & $\begin{array}{r}+0.882 \\
+0.907 \\
-\quad 7.8\end{array}$ & $\begin{array}{r}+0.933 \\
+0.919 \\
-\quad 13.2\end{array}$ \\
\hline \multicolumn{10}{|c|}{$\begin{array}{l}\mathbf{P} \text { values for each of the } 15 \text { correlation coefficients }=0.001 \\
{ }^{1} \mathrm{~d}=\text { deltoid } \\
{ }^{2} \mathrm{~g}=\text { gastrocnemius } \\
{ }^{\mathrm{r}}=\text { rectus abdominis } \\
{ }^{4} \text { Regression equation, } y+\mathrm{E}+\mathrm{b}_{\mathrm{y}} \mathrm{x}\end{array}$} \\
\hline
\end{tabular}

( $g$ or m-equiv/per $k g$ )

Fat-free Dry Weight of Dry Weight

$\begin{array}{lll}\text { Tissue } & & \\ d^{1} & g^{2} & r^{3}\end{array}$

$+0.530+0.598+0.641$

$+4.670+4.832+6 \cdot 158$

$828.8 \quad 828.6-6.2$

$d^{1} \quad g^{2}$

$+0.863+0.920$

$+5.665+5.777 \pm 5.0$

$+232.4+263.8$ co 540

Valu.s for $n:$ deltoid $=107 ;$ gastrocnemius $=103:$ rec

TABLE IV

MEAN VALUES AND STANDARD ERRORS (IN PARENTHESIS) FOR WATER, SODIUM, POTASSIUM, AND THE SUM OF SODIUM ANDCS POTASSIUM FOR DELTOID, GASTROCNEMIUS, AND RECTUS ABDOMINIS

Muscle Samples

Fat-free Dry Weight Tissue (g or m-equiv/kg)

Tissue Water (m-equiv/l.)

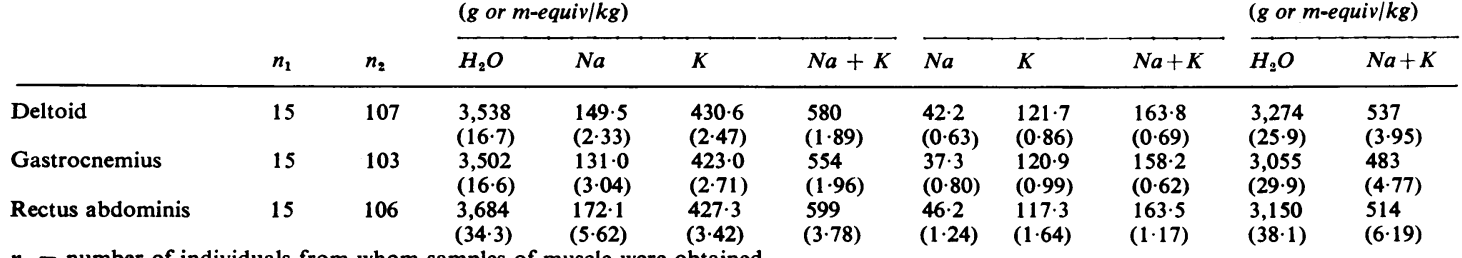

$n_{1}=$ number of individuals from whom samples of muscle were obtained.

$n_{2}=$ total number of samples of muscle analysed.

TABLE V

RESIDUAL VARIABILITY OF VALUES FOR POTASSIUM, SODIUM, AND WATER AFTER SPECIFIED REGRESSION ${ }^{1}$

Muscle Coefficient of Variation (\%)

\begin{tabular}{|c|c|c|c|c|c|c|c|c|}
\hline & \multicolumn{2}{|c|}{ Regression $\mathrm{K}$ on $\mathrm{Na}$} & \multicolumn{2}{|c|}{ Regression $\mathrm{Na}$ on $\mathrm{K}$} & \multicolumn{2}{|c|}{ Regression $\mathrm{Na}$ on $\mathrm{Cl}$} & \multicolumn{2}{|c|}{ Regression $\mathrm{H}_{2} \mathrm{O}$ on $\mathrm{Na}+\mathrm{K}$} \\
\hline & Litre & $\begin{array}{l}\text { Fat-free Dry } \\
\text { Weight }\end{array}$ & Litre & $\begin{array}{l}\text { Fat-free Dry } \\
\text { Weight }\end{array}$ & Litre & $\begin{array}{l}\text { Fat-free Dry } \\
\text { Weight }\end{array}$ & $\begin{array}{l}\text { Dry } \\
\text { Weight }\end{array}$ & $\begin{array}{l}\text { Fat-free Dry } \\
\text { Weight }\end{array}$ \\
\hline $\begin{array}{l}\text { Deltoid } \\
\text { Gastrocnemius } \\
\text { Rectus abdominis }\left\{\begin{array}{l}\text { a } \\
\mathbf{b}\end{array}\right.\end{array}$ & $\begin{array}{r}5 \cdot 8 \\
5 \cdot 2 \\
10 \cdot 3 \\
4 \cdot 9\end{array}$ & $\begin{array}{l}4 \cdot 3 \\
4 \cdot 1 \\
5 \cdot 0 \\
3 \cdot 7\end{array}$ & $\begin{array}{l}12 \cdot 4 \\
13 \cdot 5 \\
19 \cdot 8 \\
19 \cdot 2\end{array}$ & $\begin{array}{l}11 \cdot 8 \\
14 \cdot 9 \\
20 \cdot 5 \\
15 \cdot 7\end{array}$ & $\begin{array}{l}10 \cdot 8 \\
10 \cdot 1 \\
10 \cdot 1^{1} \\
10 \cdot 9^{2}\end{array}$ & $\begin{array}{c}11 \cdot 7 \\
10 \cdot 1 \\
9 \cdot 4^{3} \\
17 \cdot 0^{4}\end{array}$ & $\begin{array}{l}4 \cdot 1 \\
3 \cdot 8 \\
7 \cdot 1 \\
4 \cdot 8\end{array}$ & $\begin{array}{l}4 \cdot 2 \\
3 \cdot 9 \\
7 \cdot 4 \\
3 \cdot 8\end{array}$ \\
\hline
\end{tabular}

${ }^{1}$ Values quoted per fitre tissue water, per $\mathrm{kg}$ fat-free dry weight and per $\mathbf{k g}$ dry weight.

'Residual standard deviation $=\mathrm{S}=4.71 \quad$ a 15 subjects (Table I)

${ }^{3} \mathrm{~S}=4.05$

b 9 fit subjects only (Table I)

$S=16.4$

${ }^{5} \mathrm{~S}=23.0$

TABLE VI

MEAN VALUES AND STANDARD ERRORS FOR WATER, SODIUM, POTASSIUM, AND THE SUM OF SODIUM PLUS POTASSIUM FOR $\stackrel{\oplus}{\overparen{\not}}$ RECTUS ABDOMINIS FOR 74 SAMPLES FROM NINE FIT SUBJECTS

\begin{tabular}{|c|c|c|c|c|c|c|c|c|}
\hline \multirow[t]{2}{*}{ Reference Base } & \multicolumn{2}{|c|}{ Potassium } & \multicolumn{2}{|c|}{ Sodium } & \multicolumn{2}{|c|}{$N a+K$} & \multicolumn{2}{|l|}{ Water } \\
\hline & Mean & $S E M$ & Mean & $S E M$ & Mean & $S E M$ & Mean & $S E M$ \\
\hline $\begin{array}{l}1 \mathrm{~kg} \text { fat-free dry weight } \\
\text { Tissue water }\end{array}$ & $\begin{array}{l}438 \cdot 1 \\
120 \cdot 7\end{array}$ & $\begin{array}{l}2 \cdot 37 \\
0 \cdot 88\end{array}$ & $\begin{array}{r}136 \cdot 4 \\
37 \cdot 4\end{array}$ & $\begin{array}{l}4 \cdot 11 \\
1 \cdot 07\end{array}$ & $\begin{array}{l}574 \cdot 5 \\
158 \cdot 1\end{array}$ & $\begin{array}{l}3 \cdot 29 \\
0 \cdot 86\end{array}$ & $\begin{array}{l}3,638 \cdot 2 \\
-\end{array}$ & $\begin{array}{l}16 \cdot 72 \\
-\end{array}$ \\
\hline
\end{tabular}



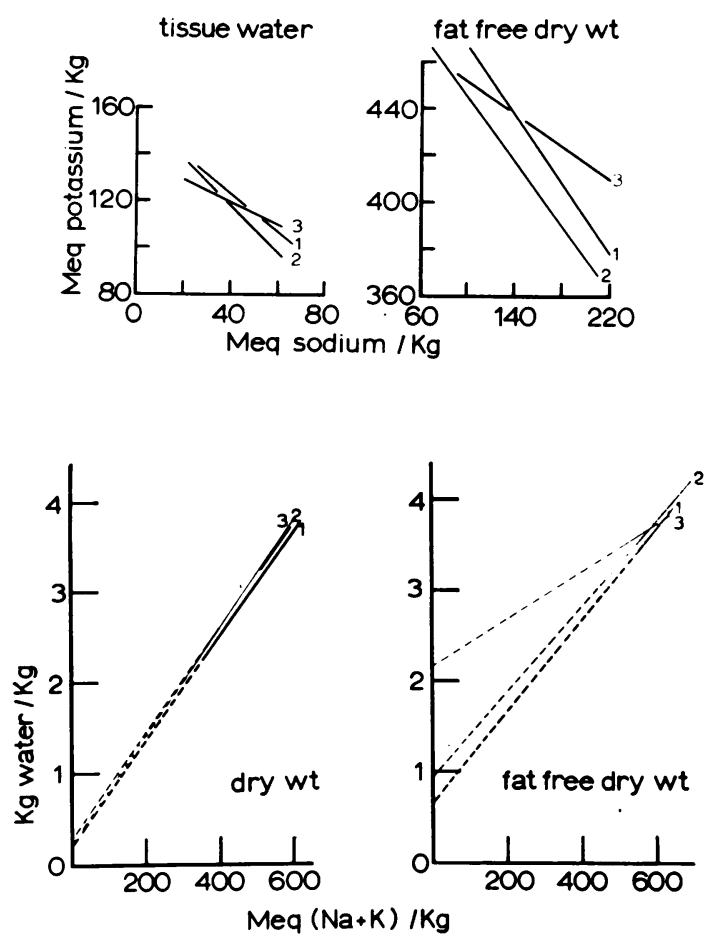

FIG. 4. Regression lines, $\mathrm{K}$ on $\mathrm{Na}$, water on $\mathrm{Na}+\mathrm{K}$. Range of observed values indicated by solid lines. Lowest value $\mathrm{Na}+K$ for rectus abdominis $=320$ m-equiv.

$1=$ deltoid

2 = gastrocnemius

$3=$ rectus abdominis: nine fit subjects only.

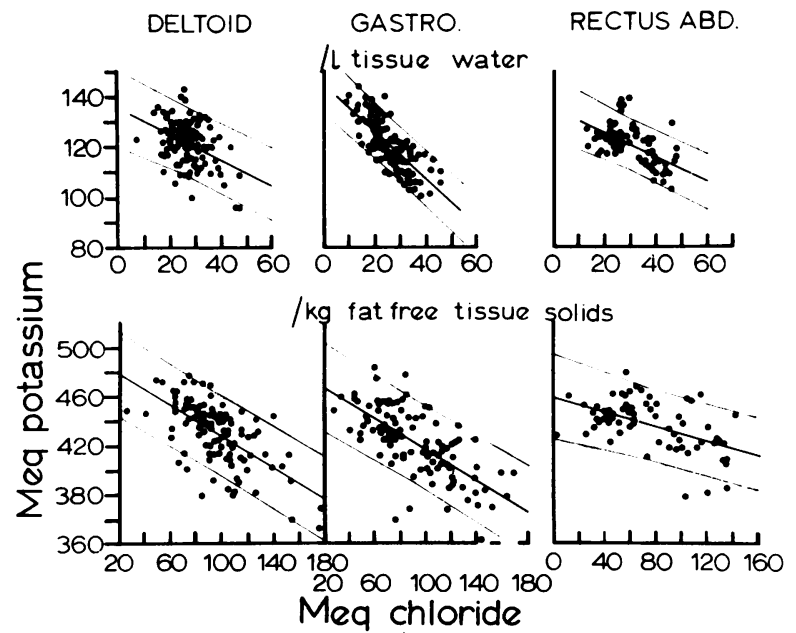

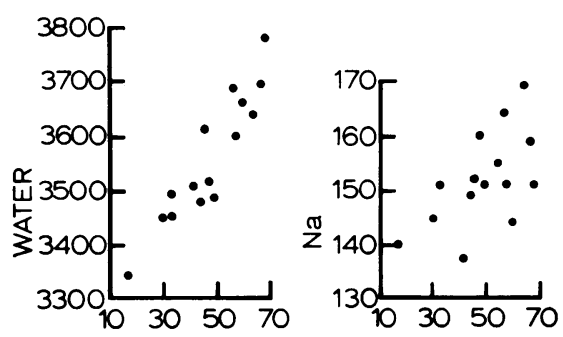

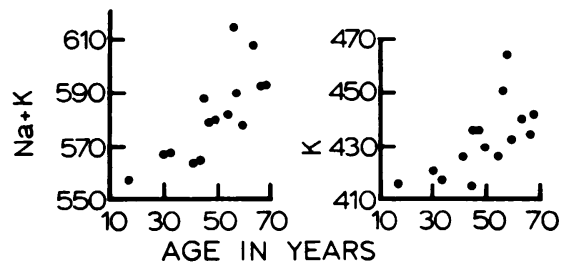

FIG. 6. Average values for water, $\mathrm{Na}, \mathrm{K}$, and $\mathrm{Na}+\mathrm{K}$ contents of samples of deltoid in each of 15 fit individuals, plotted against the individual's age in years. Amounts are quoted per $\mathrm{kg}$ fat-free dry weight of tissue.

FIG. 5. Potassium and chloride contents of samples from each of the three muscles. Deltoid and gastrocnemius, data from 15 fit subjects; rectus, data from the nine fit subjects. Calculated regression lines ( $\mathrm{K}$ on $\mathrm{Cl}$ ) and the $90 \%$ confiderce limits of the individual estimations are shown. All six correlation coe fficients are less than -0.4 , with $P$ values $<0.001$. 
litre of tissue water. When potassium and chloride are quoted per kilogram fat-free dry weight of tissue, the similar coefficients of variation are $4.6 \%, 4.9 \%$, and $4.0 \%$. These values may be compared directly with the values in the first two columns of Table $V$.

The correlation between sample contents of water and $\mathrm{Na}+\mathrm{K}$ is given sharper and more precise definition when these amounts are quoted per kilogram dry weight of tissue than when quoted per kilogram fat-free dry weight (Figs. 2 and 4 and Table III).

Deltoid and gastrocnemius are remarkably similar in composition; relationships between constituents (Figs. 1 to 4 and Table III) and the range of values for water, sodium, potassium, and chloride do not differ significantly. The composition of rectus abdominis, on the other hand, exhibits a number of more marked differences. First, many samples of rectus muscle were richer in sodium and poorer in potassium than any from either deltoid or gastrocnemius (Fig. 1); secondly, individual values scatter more widely about regression lines (Table $\mathrm{V}$ ); and thirdly, relationships between potassium and sodium (per litre tissue water) and between water and $\mathrm{Na}+\mathrm{K}$ differ substantially from those seen in deltoid and gastrocnemius (Table III and Figs. 1 and 2). The first and second of these differences disappear when data from only nine of the subjects are considered (Tables V and VI), with the sole exception of the residual scatter of sodium about the regression line, sodium on chloride. Data for the nine subjects shows greater scatter of sodium about chloride than for the 15. This increase is genuine, when data are quoted per kilogram fat-free dry weight of tissue; it is spurious when 1 litre of tissue water is the reference base and results from differences in average value for sodium in the two groups (see $S$ values appended to Table V). The third difference between data for rectus abdominis and data for deltoid and gastrocnemius remains, as far as the relationship between sodium and potassium is concerned (Fig. 4 and Table VII), but is not apparent for the relationship between water and $\mathrm{Na}+\mathrm{K}$ when these values are quoted per kilogram dry weight of tissue (Fig. 4 and Table VII). Excluding iv data from the six control subjects of Table I restricts $i r$ ranges of values for sodium and chloride but does not $c$ affect the regression sodium on chloride. Tables VI $G$ and VII summarize the data from the remaining nine 을 subjects.

The coefficient of variation of a single estimation of $\mathcal{D}$ potassium, when the sodium content of the sample $\frac{D}{\square}$ (Table V) is taken into account, is for deltoid, $\stackrel{(1)}{7}$ gastrocnemius, and rectus abdominis in the nine fit $\bar{\Phi}_{\mathbb{D}}$ subjects less than the figure previously cited for a single muscle sampled in several subjects (Flear and $\vec{\odot}$ Florence, 1963; Flear et al, 1965). This may reflect the greater care with which the present subjects were chosen. For all three muscles, this coefficient of variation is greater when potassium content is quoted per litre of tissue water than when $1 \mathrm{~kg}$ fat-free dry weight of tissue is used as a reference base. This was $\mathbb{D}$ noted previously (Flear et al, 1965).

AGE, SEX, AND COMPOSITION OF MUSCLE IN FIT AND CONTROL SUBJECTS The data suggest that age affects the water and electrolyte content of muscle in adults, and findings for deltoid muscle are shown in Figure $\frac{?}{0}$ 6. This is equally apparent for gastrocnemius when data from males and females are considered separately. The existence of differences in composition in $ᄋ$ the two sexes obscures relationships with age when data from men and women are considered jointly. At 음 all ages, samples from men tend to contain more $D$ potassium for a given amount of sodium (m-equiv 을 per kg fat-free dry weight or m-equiv per litre tissue $\mathrm{N}$ water) and less water (per m-equiv $\mathrm{Na}+\mathrm{K}$ ) than from women.

Samples of rectus abdominis similarly contain, on average, more sodium and more of the sum $\mathrm{Na}+\mathrm{K}, \underset{\sigma}{\sigma}$ the older the subject biopsied. They do not contain 6 more water, and in contrast to samples of either $\frac{\bar{D}}{\mathrm{D}}$ deltoid or gastrocnemius, contain less potassium. $\stackrel{\mathscr{C}}{+}$ The average content of sodium and chloride in a $T$ sample shows a positive correlation with the individual's age, when these amounts are quoted per $\cong$ litre of tissue water. Neither deltoid nor gastroc- $\mathbb{D}$ 

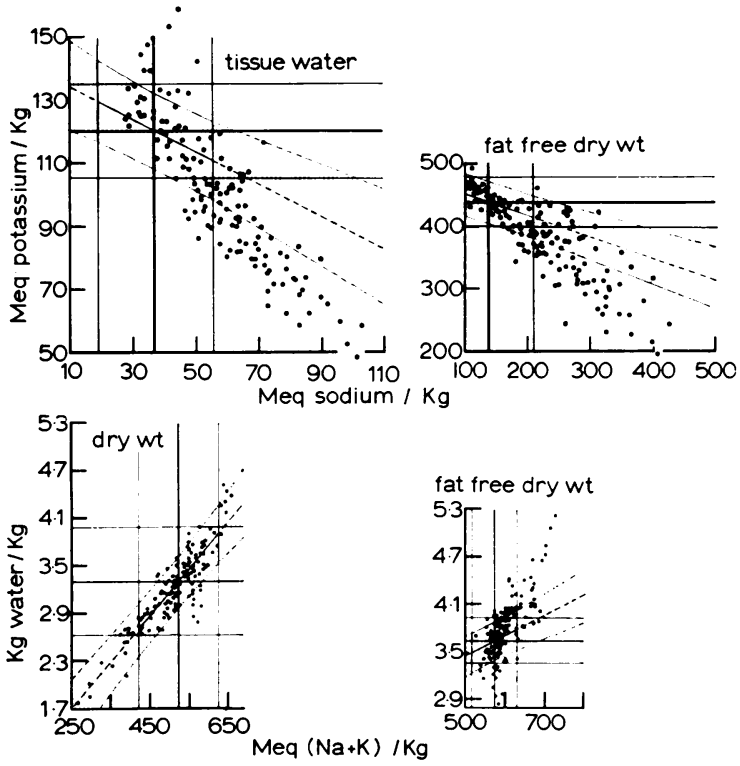

nemius show relationships between age and sample content of any electrolyte when tissue water is the reference base used.

ILL SUBJECTS Values for sodium and potassium contents of samples of rectus abdominis from five unwell subjects (Table II) are presented in Fig. 7 together with values from the six control subjects (Table I). Summarizing statistics for similar data from the nine fit subjects are depicted on this figure. Very many samples contained more sodium and less potassium than encountered in fit subjects, and residual variability of potassium (or sodium) after regression on sodium (or potassium) is clearly inflated. This variability was not actually calculated since the group of 11 subjects, clinically, are not a homogenous group. Values for water and $\mathrm{Na}+\mathrm{K}$ per kilogram dry weight of tissue in the unwell (five from Table II plus six from Table I) did not differ systematically from these in the fit subjects, apart from both a greater overall range and greater residual variability in values for water after regression on sample content of sodium plus potassium (Fig. 7). Expressed per kilogram fat-free dry weight of tissue, a different relationship was also apparent in data from the ill (Fig. 7).

Many of the values for sodium and chloride in samples from the 11 unwell subjects were higher than those found for samples from the nine well subjects. Residual variability was clearly inflated. The relationship between sample contents of sodium and chloride did not differ from that obtaining in the well subjects.
FIG. 7. Potassium and sodium contents, and water and $\mathrm{Na}+\mathrm{K}$ contents of samples of rectus abdominis from 11 ill subjects (six 'control' subjects of Table I, five subjects of Table II).

Standards are shown for rectus, based on the nine fit subjects (Table I).

Mean values and regressions $y$ on $x$ are shown, together with $95 \%$ confidence limits.

\section{DISCUSSION}

RELIABILITY OF TECHNIQUE OF SAMPLING MUSCLE Present data were obtained from samples cut from biopsies taken at operation under general anaesthesia. Elsewhere (Flear, Florence, and Williams, 1964), using the data for deltoid muscle, we have stated that muscle relaxants do not affect the water or electrolyte content of samples. Similarly, samples of rectus from subjects given short-acting relaxants, whose effect would have worn off before biopsies were taken, do not differ systematically in any respect from samples taken from subjects given long-acting relaxants. It is concluded that samples taken at operation under general anaesthesia are acceptable as a basis for deriving standards of composition, but it must be asked if the technique of sampling can affect composition systemically.

The possibility that roughly handling muscle while taking a biopsy might affect its composition, and that water might be lost by evaporation in the interval between taking a biopsy and analysing it were both investigated and rejected.

Samples from a biopsy taken from an area of muscle that had been stimulated to vigorous contraction for some five minutes or more did not differ in composition from samples from a region not so stimulated. The data will be presented elsewhere.

When a biopsy is cut as soon as the muscle is exposed, placed in its sealed container and into a vacuum flask containing solid carbon dioxide, and is sliced and analysed within a few hours of freezing, the water content of slices accurately indicates the 
water content of the muscle biopsied. This is true, provided that there is no more than 20 or 30 minutes' delay in the operating theatre between excising a biopsy and placing it in its container and in contact with solid carbon dioxide, and provided that slices for analysis are taken from the centre of the biopsy. Longer delay is unacceptable. Freezing a biopsy for as long as $\mathbf{4 8}$ hours does not affect its water content.

STANDARDS FOR THE COMPOSITION OF DELTOID AND GASTROCNEMIUS We have no reservations in accepting the standards for deltoid muscle (Tables III and IV, Figs. 1 to 3); all individuals from whom samples were taken were fit. This is true also of individuals from whom we took samples of gastrocnemius muscle. However, all but two of these individuals had varicose veins, and the observations of Bracey (1961) raise the question of whether locally impaired circulation may have affected the composition of muscle. Bracey found histological evidence suggestive of cellular and/or interfibrillar oedema in soleus muscle biopsies from patients with severe venous incompetence. Either event would increase the water content of samples, and the sodium content would be enhanced, certainly in the latter case, possibly in both. The close similarity between the findings for gastrocnemius and deltoid muscle suggests that our subjects, none of whom showed skin changes or oedema, may be considered good controls. In one subject with varicose veins, samples were taken from deltoid as well as gastrocnemius muscle. There were no obvious differences in the composition of the two muscles, strongly suggesting that in this person composition was not altered by local venous stasis. For rectus abdominis muscle the situation is more complicated.

STANDARDS FOR COMPOSITION OF RECTUS ABDOMINIS: COMPARISON WITH ILL SUBJECTS In retrospect, we now consider that six of the 15 subjects originally chosen were unsuitable for inclusion in a group from which data are to form the basis of standards. Two persons, an elderly woman discovered on laparotomy to have carcinomatosis, and another woman who had been troubled for some time with biliary colic, were not considered to be fit. Their inclusion was justified originally on the grounds that neither patient showed reason for abnormal loss of water or electrolytes, that both appeared to be well hydrated, and that their serum levels of urea and electrolytes were normal. It was prompted by our reluctance to sample the rectus abdominis electively. It is becoming increasingly clear, however, that there are other causes for altered volume and composition of body fluids than simple abnormal loss of water and electrolytes, for example, disturbances of cellular metabolism and integrity of their membranes. It is moreover, not always evident when such causes are present, but seems to be inherently more probable in the ill, from whatever cause. We feel, therefore, that it is unwise to include data from any subject who is i any way unfit. On these grounds we also exclude tw of the four subjects with peptic ulcer admitted fo $\$$ surgery. Before operation all four were considereef fit: all were working until admitted to hospital, at considered themselves physically well and merely inconvenienced by dyspepsia. Events after operation in two of these patients indicate that they were less? fit than had been supposed. After a slow convalesco ence, complicated by wound infection, one person experienced such an increased feeling of well being and energy as to have no doubts in his own mind (of ours) that he had indeed been unwell before operar tion. This subject also gained weight during the first six months after operation, although weight before operation, had not apparently been substandard fom height. The second patient experienced a storm convalescence complicated by wound dehiscence an $\Phi$ infection, and in our experience these complications are often an indication of preexisting potassium depletion. We also considered that subjects with sustained weight loss should be excluded from $\stackrel{\infty}{a}$ group forming the basis of standards, as their tissuee may show in lesser degree the changes in compositio that have been demonstrated in frank undernutritio and wasting. Both remaining subjects with peptiơ ulcer had lost weight in the year before admission, neither individual had stenosis of the duodenum and clinically neither was dehydrated. We have previous 3 ly reported data for the rectus abdominis (Flear et at 1965) which included results from two persons whe had lost weight during the preceding year. Dat from them are abnormal judged by the present standards whereas similarly appraised data from the other subjects, who had not lost weight, are normat in all respects. For these reasons we prefer to basê standards for rectus abdominis muscle on data for the nine fit persons (Tables VI and VII; Fig. SP rather than on data from all of the 15 originall selected. This decision is supported alike by the close. correspondence between data from the six subjects thus excluded and the five unwell subjects from whom samples of rectus abdominis were also obtained, an 1 by the fact that two important differences betweefi data for rectus and deltoid and gastrocnemius are resolved when data from these six persons afe excluded. Thus no sample of rectus abdominis fron the nine fit persons was richer in sodium or poorer in potassium than any from deltoid or gastrocnemius and residual variability of values is reduced for potassium, sodium, chloride, and water after aof counting for the various regressions (see Table V). $\stackrel{\varnothing}{8}$ 
REAPPRAISAL OF STANDARDS PREVIOUSLY PUBLISHED We would emphasize that we regard the standards elaborated for water and electrolyte composition as provisional. As our experience increases, we are likely to recognize more precisely ways in which it is necessary to be stringent in selecting controls. Reappraisal of data from a group of 18 control subjects reported earlier (Flear, Crampton, and Matthews, 1960) suggests that even a moderate lowering of the serum level of sodium is another reason for excluding persons who might otherwise be thought suitable for inclusion among controls. Ten of the 18 subjects had asymptomatic hyponatraemia, of only moderate extent, yet were abnormal judging by standards presented here. Two of these subjects had peptic ulcer, two had carcinoma of the colon, and both had lost weight. But the remaining six subjects had apparently only trivial disabilitiesthree persons with herniae, two with haemorrhoids, one a lipoma of the breast, and yet muscle samples from them must be considered abnormal in composition. Another two from this group of 18 must also be considered abnormal: both subjects had peptic ulcer and normal plasma sodium levels. The possibility thus raised that longstanding peptic ulceration leads to abnormality of water and electrolyte, even in the absence of significant vomiting, is being investigated. Certainly the lower potassium and higher sodium content of samples from patients with peptic ulcer, which is suggestive of some degree of potassium depletion, accords well with the independent clinical experience of the nutritional and intestinal unit at the General Hospital, Birmingham. It has been noted that subjects with peptic ulcer given potassium supplements before operation have a smoother convalescence than subjects operated upon without prior potassium repletion.

IMPROVEMENTS IN STANDARDS TAKING AGE AND SEX INTO ACCOUNT The relationship displayed by our data between composition and age (Fig. 6) and the differences noted between sexes suggest that standards would be improved if age and sex were taken into account. Certainly the residual scatter of potassium about the regression line potassium on sodium (m-equiv per $\mathrm{kg}$ fat-free dry weight) is less when data for the deltoid from men up to, including, and over 44 years are considered separately (residual CVs: all ages, $4.4 \%$; age $44,3 \cdot 8 \%$; over $44,3.8 \%$ ). There is a similar reduction in the residual scatter of potassium when potassium and sodium are quoted per litre tissue water but only for the group aged 44 and under. The scatter of values for water about the regression line water on $\mathrm{Na}+\mathrm{K}$ is less in both age groups when either dry weight or fat-free dry weight is the reference base used. Similar reductions in residual scatter are achieved for data from females, as well as males, when findings for deltoid and gastrocnemius are pooled, which is permissible as data for the two muscles are virtually superimposable (Figs. 1 and 2).

This work was supported by grants from the Royal Society, the Dowager Countess Eleanor Peel Trust, the Endowment Research Fund of the United Birmingham Hospitals, and the Scientific and Research Committee of the Royal Victoria Infirmary, Newcastle.

Our thanks are due to Mr Peter Dickinson, FRCS and Mr Ian McNeill, MS, FRCS, for cooperation in some of the methodological investigations, and to Mrs Lewis and the Department of Photography. University of Newcastle, for cartographic assistance.

\section{REFERENCES}

Bracey, D. W. (1961). Brit. J. clin. Pract., 15, 357.

Cotlove, E., Trantham, H. V., and Bowman, R. L. (1958). J. Lab. clin. Med., 51, 461

Flear, C. T. G., Carpenter, R. G., and Florence, I. (1965). J. clin. Path., 18, 74.

$\longrightarrow,-,-$. Unpublished.

Crampton, R. F., and Matthews, D. M. (1960). Clin. Sci., 19, 483.

and Florence, I. (1961). Clin. chim. Acta, 6, 129.

(1963). Nature (Lond.), 199, 156.

, and Williams, J. A. (1964). Proc. Ass. clin. Biochem., 3, 139. 